\title{
SOME POSSIBLE ORIGINS OF ST. GEORGE'S DAY CUSTOMS AND BELIEFS
}

\section{$\underline{\text { Mall Hiiemäe }}$}

Of all tradition accounts relating to spring days in the Estonian popular calendar nearly one third pertain to St. George's Day (jüripäev) that, no doubt, refers to a very special position of the day.

Throughout the Baltic provinces St. George's Day became the date when juridical and labour contracts were concluded. This was also the beginning of corvée, of the leasehold year, of taxpaying and of entering service. Thus, playing an important role in the peasants' economic life, the date bore a very strong social meaning, which made the concentration of various customs not surprising at all.

St. George was a cavalryman who died a martyr's death in 303 A.D. when Rome was governed by an anti-Christian emperor Diocletian. Later, he became associated with the legend of a mythical dragonkiller, known both in Europe and in Asia. As the legend fitted to symbolize the victory of Christianity over paganism it got reflected in iconography as well. Hence the image of St. George as a brave warrior, victor and miracle-worker. And this is why the so-called George's Thaler was considered one of the most precious amulets in the 16th-17th century European wars.

Taking a closer look at the Estonian customs and beliefs connected with St. George's Day, and comparing them with the corresponding material from other peoples, one will notice various mutual influences, transferences and mergers of customs of different epochs. It was even before the 13th century arrival of the Teutons to introduce Christianity and to tell the people of the deeds of saints that an idea of St. George had filtered into Estonia, probably coming from the Eastern Slavs. As we know, the Kiev-Russian Principality that existed in the 9th-12th centuries, stretching from the Black Sea to Lake Ladoga, adopted Christianity in the late 10th century thus creating favourable conditions for the development of a cult of saints. South-East Estonia maintained close contacts with that state, especially after the conquests of Yaroslav the Wise of 1030 and the consequent erection of the fort of Yuryev (Tartu). The halo of Yegor the Brave was transferred to the victorious conqueror Yuri Dolgoruki (ab. 1090-1157), while the destruction of heathen evil once again served to justify territorial expansion: "While building towns and villages, taking care of the spreading and consolidation of Christianity in the Finnish North, Yuri Dolgoruki declared Saint Georg the Brave ('Hrabryi') to be his patron saint in his struggle against the wild, virgin nature and the Finnish and kindred infidels living in northern Russia. This is way he would build the first churches as dedicated to Georg the Brave as is proved by the Nikonov Chronicle." (Kalinski 1877, 393-394).

In the popular calendar, however, April 23 (May 6 O.S.) seems to owe its relative importance to something more than just certain personal deeds, however remarkable, of the noble martyr George to whose memory the day is dedicated. It is hard to believe that the commemoration day of a saint even if associated with the dragon-killing legend and with the destruction of heathen evil - could ever have attracted such a host of folk customs if the martyrdom had not happened in spring, around certain essential phenological changes.

Perhaps the richness of the tradition accumulated on St. George's Day should rather be viewed in the light of the fact that the Greek form Georgius means a ploughman, a cultivator of land. And when trying to divine the ancient predecessor of the holiday, one should better consider such tradition that is connected with spring-time vegetation as well as the concentration of special customs on certain pre-Christian dates to mark the awakening of nature and the arrival of spring. In the Estonian ma- 
terial on St. George's Day, collected in the 19th-20th centuries, this aspect is, however, eclipsed to a certain extent by information connected with means of livelihood. Once there must have been more than one date marking arrival of spring, based on different motivations such as, e.g. the solar calendar (the vernal equinox); phenological changes (the melting of the snow, the beginning of a massive spawning migration); means of livelihood (for agricultural people - Sowing Day, for fishermen - the end of ice-fishing or the start of the spring-time fishing season, etc.). According to our oral calendar tradition, plant life can start when the average temperature of the air has reached $0^{\circ} \mathrm{C}$, which is believed to happen on Lady Day (March 25). On that date we find reports of weather and harvest forecasts based on such omens that could earlier have been associated with the equinox. The same date is reported to start the spawning migration of the pike, that is observed in South-East Estonia and in the parish of Iisaku. In Iisaku it has even motivated a peculiar feast "with the eating of dry pike" that is held in the village of Lemmaku in order to sustain fishermen's luck (Hiiemäe 1981, 23).

The St. George's Day traditions connected with the awakening of nature and the arrival of spring make one think of the actual emergence of green planta. The idea of a dying and newly rising deity, in association with the autumnal fading and springtime bursting of vegetation, seems to fit ever so logically into the world view of peoples living in a natural state. There are, for example, such Russian proverbs as George will bring spring and There is no spring without George (Dal 1957, 879). At the same time, St. George's Day marks new opportunities for finding food. The Finns have a parallel to the South-East Estonian proverb St. George comes with his fish basket (Kuusi 1985, 120121). The East-Slavic saying about St. George bringing along grass is better known in the central regions where the climatic conditions are similar. The Estonian proverb With his key Georg makes the grass grow seems to have a parallel in the fragmentarily survived runic song In George's pocket are the keys to Heaven, in George's bosom are the keys to Hell. St. George also brings along spring and new alimentation according to the Lithuanian tradition. He is addressed as the keeper of the keys of summer and asked to make the grass grow and to disperse the clouds (Skrodenis 1968, 264). Of course it may happen that cattle-breeding peoples start marking the appearance of new grass on one and the same date quite independently of one another, yet similar wordings refer to at least some contacts within the Eastern-Slavic - Balto-Finnic - Baltic cultural area, if not a common development. There are also a few reports of St. George's Day marking the emergence of green plants in the German-speaking area. Notably, in the South-Germanic part of the Alps grass is reported to have been "called forth" with noise, while the absence of greenery before St. George's Day is considered a good omen (Handwörterbuch III 1930/31, 649-650). Germans, as well as Southern Slavs bring green plants near their living quarters on that day in order to mark the coming of spring (Frazer 1983, 126-128). The Estonians, however, do it mainly at Whitsuntide and Midsummer.

Another important belief lying at the base of St. George's Day's customs concerns the earth being poisonous until vegetation has started. Evidently this belief also originates in a pre-Christian imagery connected with nature's awakening. An example from South-East Estonia: Before St. George's Day one must not sit on the ground as the earth has not been able to breathe yet and so it may cause diseases (RKM II 66, 515 (3) < Häädemeeste 1957). The ban on sitting on the ground is more familiar in South-Estonia, applying especially to herdchildren (South-East Estonia, esp. Vastseliina and Setu). Although the ban on walking barefoot is also known to have applied to some other spring days (e.g. Ascension Day), an absolute majority of the reports (over a hundred) mention St. George's Day. The Germans forbid their children to walk barefoot and lie down on the ground by saying that "the cold has not left the soil yet" (Handwörterbuch III 1930/31, 656).

The belief that the earth is poisonous, has yielded quite a number of practical rules. The fact that sometimes instructions disagree for one and the same day or period is perhaps not so much the 
result of forgetting (as the case may be with a custom on its way out) as of different applications of one and the same basic image. On the one hand, avoidance of contact with earth produces taboos and interdictions, on the other hand, however, it leads one to take advantage of the released powers to be used in any sphere of life, either for prevention or for black magic. According to the Estonian beliefs, walking barefoot before St. George's Day could cause skin diseases, swellings and cracked skin, yet unlike sitting on the ground, walking barefoot could also be considered from a positive angle, as contact with magical powers could be used for witchcraft. According to some East Slavic beliefs the dew is dangerous on St. George's Day as the earth is poisonous, but there are also reports of its sanatory effect, becoming manifest especially when one wallows in it, or if the cattle is let out to graze on the dewy grass to keep healthy later. At the same time one is warned against letting the chicken out lest they should start losing eggs (Shapovalova 1974, 125; Tolstaya 1984, 198). And one more example of negative connotation: "Sages and wizards share a tradition according to which the early dew of St. George's Day is especially harmful for cattle. Therefore they go out into the fields to collect the dew. This is done by soaking a linen cloth in the morning dew. They say that St. George's dew causes horned cattle to lose flesh, cows to lose milk, and calves to lose their eyesight. Just cover the animals with the soaked cloth and troubles will come flooding upon them. There is only one preventive measure - to flog them with catkins when let out to graze on St. George's Day" (Sakharov 1989, 259). It is especially characteristic of the Slavic peoples, but also of the Hungarians, to consider (map *1) bathing before St. George's Day a healthy thing to do. According to a majority of the collected tradition this belief also holds for the Estonians. The Germans believe that from St. George's to St. Lawrence's Day (August 10) there is no poison or danger in the water (Beitl 1955, 252), while one is warned against contact with water before St. George's Day. Note the typical interdiction and argument: Nobody must drink out of a spring as on that day the earth will open up and let out all its poison (Handwörterbuch III 1930/31, 654-655).

Logically, various practices of folk medicine are also connected with beliefs in the release of the poisons of the earth and their magic powers. Here belong a rich arsenal of techniques seeking good health, fertility and stamina for horses, but also human welfare. Another notable trait is the concentration of folk practices of beauty treatment, for which St. George's Day stands out against all the other dates of spring and early summer. Here the temporal aspect is also very important. The procedure had to be applied strictly before or on St. George's Day. The face could either be cleaned with snow (South-Estonia, over 20 reports) or with birch sap (ab. a dozen reports) or one could have a sanatory bathe (over 80 reports, less from western Estonia) - all in order to acquire a fair, clean and unfreckled complexion and to avoid skin diseases.

More than one tenth of the reports concerning St. George's Day customs in Estonia, have something to do with snakes. It seems that the day has attracted snake-bound instructions in quite an unusual proportion. Evidently the image of St. George as a legendary dragon-killer has been impressed on people's minds even deeper by the traditional depicting of St. George together with the defeated dragon on icons and the so-called George's Thaler that was worn as a charm. With time, the dragon became identified with a snake as a symbol of evil. The Estonian tradition concerning snakes contains two kinds of reports: mostly, the snake is used in repelling and preventive magic to help the cattle thrive and people fare well and also to cure people's diseases, while a lesser part contains instructions on how to avoid snakebites in the coming summer. The following list presents various cases where a snake can help: success in enterprises, the avoiding of master's wrath, good luck in court, no tiring at work, lots of money, luck with cards, competence in bird language (and the possession of other miraculous powers), prevention of evil witchcraft, means of witchcraft; treatment for snakebites, toothache, boils, swellings, alcoholism, lumbago, stroke, flatulence, rheumatism, rickets, barrenness; it could also be used as a component of a corroborant or an appetizer; a stick with which a snake had been killed was said to protect one from Old Nick, or - if placed under the 
eaves - from fire, and if stuck into grain it was to secure good crops, to keep the dart moth off the young green crop, etc. Once again one should note the fixed time: the magic powers are attributed to a snake killed before St. George's Day, even if used later (in a dried form, or made into powder, ashes, or infusion in oil or spirits). So this rich and living tradition, acquiring ever new nuances, seems to be supported by a much older belief: the adder gets its special powers from the unbreathed and therefore still poisonous spring soil, cf. the following saying from the parish of Põlva: Before St. George's Day the snake is said to be a stronger medicine than after it (ERA II 63, 66 (125) Põlva 1933). And again one can find an opposite interpretation: according to some German beliefs snakes are not poisonous before St. George's Day as it is only since that day that the poison of the earth enters the snakes and toads (Handwörterbuch III 1930/31, 656; Beitl 1955, 552). Hence we can see that one and the same basic belief may produce similar as well as different practices in different cultures or within one culture, without even reflecting cultural contacts or their absence. A legend of a saint, even if propagandized to justify military expansion (the snake standing as a symbol for heathen evil) would hardly have sufficed to motivate such a variegated folk tradition as we know it today unless it had a pre-Christian background. Compare the cult of St. Margaret who is also depicted as a dragon-killer. There is a Finnish custom to take a drink for "killing the snake" before going out to make hay on St. Margaret's Day, but that is all there is to it (Vilkuna 1982, 178181).

Since the 12th century St. George started to be depicted as fighting the dragon from horseback. This has motivated his becoming a substitute for the patron of horses. Reports to that effect have been received from many nations: Germans, Hungarians, Poles (Handwörterbuch III 1930/31, 652), Russians (Propp 1963, 29), Latvians (Shmits 1940, 749-752) a.o. According to visitation reports sacrifices have been made to St. George as the god of horses at Kiidjärve, Estonia, as late as 1680 (Kõpp 1902, 14). The following text was put down on the isle of Kihnu in 1951: Formerly one would not go out with a horse on St. George's day. This was to the memory of his once fighting a winged snake - something like a devil. Jüri /George/ had been on horseback and won a victory, so it's something like a horses' holiday (RKM II 1, 418 (24) Kihnu 1951). And the origin of the two St. George's Day celebrated in Setu (the winter holiday is on 26 November) is known among the local people even nowadays: It's St. George's Day. he is the animals' patron too. A beast came out of the sea and every day a human was given and then the princess was to go. She cried very pitifully. And then came St. George on a white horse. St. George drove a lance down the beast's throat. So God gave him two holidays for saving the people. In Värska there is St. George's Curch. The horses were all taken to the church to be whisked with holy water. And a service was held (RKM II 290, 660 (12) Setu 1972). The custom of honouring horses on St. George's Day we share with our eastern and southern neighbours. Although the Finns, like the Western Europeans, recognize St. Stephen as the patron saint of horses, they also say that St. George's Day is a "horses' holiday." The Latvians and the inhabitants of the western and southern parts of Estonia and also of Saaremaa, share the ban on riding a horse and ploughing with one unless they are prepared to risk losing their luck with horses and being afflicted with other trouble. There is a rather distinctly defined area in Mulgimaa and southern Tartumaa where (map *2) a black rooster would be killed in stables, but this kind of sacrifice was also committed on Michaelmas and St. Martin's, even on Christmas. In addition, the Latvians know several other methods practised on St. George's Day to improve the horses' looks and staying power, and for them the day also marks the beginning of the herd to be tended at night (Shmits 1940, 749-752). The custom of giving the horses a sanatory swim that is known mostly in South-East Estonia, but also in Eastern Estonia, we share with Russians, but Latvians practice it as well. The whole tradition has a clear eastern colouring. Although St. George's Day is the most important Estonian date connected with horses, the tradition is overshadowed by the tending of cattle. This is not surprising as in Estonia horses began to dominate over oxen in field 
labour only as late as the 19th century. Cattle also stands in the foreground for those Russians who live in the Setu area. O. Loorits has said: St. George's patronal functions extended from horses to all domestic animals. Beside the "horse's holiday" and even to a greater extent than that St. George's Day is celebrated as a "holiday of cattle" by the ethnic Russians living in Estonia (Loorits 1941, 22). In fact, cattle tendence dominates the whole East Slavic tradition of St. George's Day celebration, while the customs observed are not quite in accord with those concerning horses. The same holds about the Setu people. They regard St. George as a horses' patron all right, but this belief has been supported strongly by the ceremonial blessings of the horses brought to the church: On St. George's Day the horses were taken to the church and unharnessed. There were horses from every village. They were gathered on an open place. There the priest burnt incense and blessed them. There was a pail with water and a whisk in it, with that whisk he threw water at the horses and said: "Saint George, keep the horses from misfortune." An icon with St. George was also in his hand. Then the people said: "Now the horses are blessed." Everybody had his herdchildren also along at church. The herdchildren stood all near the priest. Then the priest blessed them so that St. George would let everybody live in peace, people as well as the animals" (ERA II 310, 154/5 (14) Setu 1942). Horses do not play a conspicuous part on the day when the cattle is let out to graze for the first time either in the parishes of Setu, Vaivara, Torma, Iisaku or in the Russian-influenced part of Kodavere. (map *3) Images, including hose of St. George and St. Nicholas, were carried around the cattle, the animals as well as the herdchildren were whisked with holy water, the animals were hit with the willows that had been consecrated in church on Palm Sunday - all in order to make the cattle thrive. Horses were also brought out to be blessed: On the morning of St. George's Day the animals were driven out to the fallow, the horses as well. Then George was brought out the chapel and carried around the chapel. The people who were there, herdchildren as well, passed from under the image. After that George was carried around the animals (ERA II 286, 166 (142) Setu 1940).

Proceeding now to that layer of St. George's Day customs that originates in the Estonian day for letting the cattle out for the first time (April 1), we find that the transference is temporally justified. The average daytime temperatures rise over $5^{\circ} \mathrm{C}$ and the vegetation starts around 10 April, while $10^{\circ} \mathrm{C}$ which means intensive vegetation, associates with 15 May (Atlas 1978, 12). Consequently, grass begins to grow somewhere between the old and new style St. George's Days. By the 20th century the whole set of customs connected with the day of letting the cattle out had been transferred to St. George's Day quite easily, but in addition the day of the week is considered, and sometimes also the direction of the wind or the phase of the Moon (Rantasalo 1941, 6-28). The neighbouring peoples may let their cattle out to graze for the first time on various dates of the church calendar, but if it happens to be St. George's Day, the customs acquire some specific traits. The legend of St. George on horseback supports his image as (map *4) a herdsman of wolves. The idea is current both with Germanic and Slavic peoples. The corresponding Estonian image bears traces of influence received from either side. Thus St. George was transformed into a ruler of wolves, who bridled his subjects on St. George's Day forbidding them to kill domestic animals from the day onwards. The image being vital for a cattle-breeding people their customs observed on St. George's Day in connection with cattle are numerous. It is not surprising that the corresponding Estonian material is not so much associated with general cattle-oriented witchcraft that is practised to an almost equal extent and practically in the same ways on other dates of spring and early summer, like Maundy Thursday, Ascension Day, St. John's Day, as with the cattle finding themselves in another environment after a long stay in their winter quarters. A number of instructions require strict adherence to dates, either before or after St. George's Day (e.g. one is (map *5) forbidden to build a fire before the day, but recommended to do so after it; the above-mentioned use of a pre-Georgian snake for preventive purposes, etc.). However, if the cattle is let out on April, for example, there is no 
such differentiation. St. George as a herdsman of wolves has developed into quite a clear-cut image of a guardian-spirit. Both Estonian and Russian incantations appeal to a forest spirit called St. George pleading him to change into the guardian of cattle. In the Russian tradition, the motif of St. George as a master of wolves is not well known. Some possible reasons are suggested by O. Loorits: "The whole material obviously bears a Byzantine-Russian colouring and like the Latvian tradition, resembles, first and foremost the Byelo-Russian material. No doubt the Estonian and Latvian data point once again to the ancient Kiev-Polotsk line, successfully preserving the older layer, whereas the local Russian tradition is younger and - originating in Central Russia - does not contain such material at all" (Loorits 1941, 40).

The history of the development of St. George's Day traditions, against the backdrop of other material connected with the arrival of spring, may be characterized by the biblical sentence: "For he that hath, to him shall be given: and he that hath not, from him shall be taken even that which he hath." Around St. George's Day we also find a considerable concentration of such omens that are usually not fixed to a calendar date (the spotting of the first frog or butterfly, an early breakfast before going out "to cheat the bird", etc.) or late borrowings from some other marked dates (e.g. the command that one get up early, the beginning of sleeping outside, the ban on lighting a fire in the house have all belonged to some earlier spring dates).

Further, as St. George's Day was also socially important, it attracted additional customs connected with moving from one farm to another. The first day was considered significant for the whole period of service to come: e.g. the spotting of a cat meant that the service was to last half the period only (Tartu-Maarja), the eating of pea-soup also portended an early rolling out of the place (Märjamaa), master's anger brought trouble for the whole summer (Halliste), etc. The start of counting the economic year has motivated such proverbs as: George will bind, Michael will unbind, St. George's Day will bring an after-meal nap, a sheaf of rye will take it away a.o. Here also belong the lighting of St. George's bonfires by which the new farm hands could get aquainted with each other. In Setu, according to Oskar Loorits, St. George's Day was celebrated as a village feast in as many as fourteen villages (Loorits 1952, 333), including a kirmes with a great deal of public merrymaking.

Interesting reports come from North-East Estonia where the cattle-magic practised on St. George's Day has merged with some traits of a women's holiday dating back to the tribal era (Loorits 1941, 43-64, Tampere 1965, 234-245). At that the Izhorians from beyond the River Narva, Votes, and the Russians living by Lake Peipsi demonstrated a better preservation of the Russian tradits of a women's holiday, whereas the Estonians laid greater emphasis on cattle-magic, but by the middle of the 20th century the magical churning and the (map *6) "tighting of the milkpails" degenerated into mere entertainment.

As the beginning of the economic year, St. George's Day has also absorbed the Estonian Ploughing Day (April 14). The counting of the sowing weeks that formerly used to start from Ploughing Day, was transferred to St. George's. Ploughing Day is one of the four main divisors of the year, beside Midwinter (January 14), St. Margaret's Day (July 13) and the Shedding of Yellow Leaves (October 14). Ploughing Day seems to be a landmark requiring the ploughing of at least one symbolic furrow or an inspection of agricultural implements. The possible pre-Christian background of the day is unclear. Whether it has once served as a day for practising prophylactic magic just because the day of the awakening of the earth and the beginning of vegetation did not suit that purpose - we can but guess. At any rate, the Estonians have two guiding dates for starting field cultivation. The earliest crop to be sown was oats and that sowing was recommended to start before St. George's Day.

There is an Estonian proverb: Since St. George's Day the Pleiades go up in the morning sky and the ox will go on the furrow. Similarly, the Russians mention the beginning of field cultivation in When 
George comes, the plough will go to the field (Dal 1957, 880). And the Finns say: George will take the plough to the field (Hautala 1948, 183). It has become common knowledge that field cultivation should start on St. George's Day. In reality, it did not need to though. The day was considered to be $(\operatorname{map} * 7)$ a holiday for the horses in West-Estonia, the islands, and South-Estonia. Still stronger was the ban on disturbing the soil, originating in the ancient day of the awakening of the earth and the arrival of spring. The system of taboos is even clearer in the customs of Ascension Days (between May 1 and June 3, in any case after St. George's). There were considerably more reports of ploughing bans than of starting ploughing. The arguments brought to the ban are as follows: otherwise the crops will fail (Häädemeeste), caterpillars will thrive (Kärla), wild animals will do damage (Anseküla); in Risti parish "one would not yoke oxen to go ploughing, so that the animal could be protected from harm" (note that the ban was not restricted to horses only), birds will eat the harvest (Muhu), lightning will strike the house (Halliste), an accident will befall the horses (Hargla). The Latvians also avoid ploughing that day for fear of the field overgrowing with weeds, or of the horse's neck getting sore, etc. A few reports relate that it was forbidden to prod the earth or to dig holes into it, which ban may as well have been carried over from Ascension Day.

A considerable number of reports (about 70 from all over Estonia) relate of (map *8) the ban to cut down trees. Compared to other dates connected with bans on rattling and noisy works, it is quite a noteworthy amount. The argument, especially characteristic of Saaremaa and North-Estonia, reads that otherwise the forest will hate the cattle, the wolf will kill them. A dozen of other explanations mention the danger of the cows hurting themselves, East-Estonia has given a similar number or reports of a possible damage by lightning. In addition, there are a few threats that either the forest or the woodcutter will dry up, or the crops will fail, or the house vermin thrive. The number of the reports is comparable to that of reports concerning the ban on doing damage to flowers, grass and trees on Ascension Day (cf. Hiiemäe 1984, 144-148). The ban on noisy works for fear of lightning damage is spread mainly in a clear-cut region in South-East Estonia. One may surmise that the ban to cut down trees or to break twigs originates in the taboos of St. George's Day as the beginning of vegetation, but the argumentation has shifted on to cattle as the hurting of a tree became associated with the hurting or killing of an animal.

Neither does agriculture receive much attention on St. George's Day in the Russian-influenced eastern part of Estonia or among the ethnic Russians living in Estonia. The common blessing of the cattle at church was a ceremony that brought forward the importance of the day for the cattle even more, overshadowing the agricultural aspect. Still, the priest was asked to bless the fields as well, and the willow-catkins kept since Palm Sunday were thrusted into young rye seeking to ensure a good harvest. The agricultural customs of the Slavic people, however, are known to have been much richer than here: for example, the Russian and Byelo-Russian rituals include the eating of some ritual food (boiled eggs, pie, baked figurines) just in the field, and there were some procedures to draw forth rain, while the Ukrainians used to walk round the newly sown field, or just inspect the fields, etc. (Shapovalova 1974, 127-129). Some customs can also be referred to social relations and historical events. The Estonians, for example, make St. George's Night's bonfires, organize torchlight processions and special running and orienteering races, to mark the famous uprising of 1343.

Here the historical motivation has been mediated mainly by the historical narrative "Tasuja" ("The Avenger") by E. Bornhöhe. The older generation still remembers St. George's Day as the day of changing service, the enactment of contracts of employment, the starting of field cultivation and the letting of the cattle out to graze for the first time, and also as the nameday of Jüri (George). The most persistent of the traditions has been to regard St. George's Day as an orientator of phenological or natural observations in general. Even nowadays certain phenological characteristics are used in popular weather forecasting for shorter and longer periods, or in guessing whether the spring will 
develop rapidly or slowly, and in planning the harvest-time, trying to guess its weather and the crops. So, part of the traditions connected with St. George's Day as the beginning of spring are with us even today, originating, though, in very old times.

Translated by Kai Vassiljeva

\section{Literature}

Atlas Estonskoi SSR 1978. Moskva.

Beitl, Richard 1955. Wörterbuch der deutschen Volkskunde. Stuttgart.

Dal, V. 1957. Poslovitsy russkogo naroda. Moskva.

Frazer, James Georges 1983. Zolotaya vetv II. Moskva.

Handwörterbuch des deutschen Aberglaubens III. 1930-1931. Berlin, Leipzig.

Hautala, Jouko 1948. Vanhat merkkipäivät. Suomalaisen Kirjallisuuden Seuran Toimituksia 229.

Helsinki.

Hiiemäe, Mall 1981. Eesti rahvakalender II. Tallinn.

Hiiemäe, Mall 1984. Eesti rahvakalender III. Tallinn.

Hiiemäe, Mall 1992. Ida-Virumaa rahvakalendrist. Ida-Virumaa rahvakultuurist. Tallinn, pp. 67-81.

Kalinski, I. P. 1877. Tserkovno-narodnõi mesjatseslov na Russii. Zapiski Imperatorskogo Ruskogo Geograficheskogo Obchshestva po otdeleniju etnografi VII.

Kuusi, Matti (et al.) 1985. Proverbia septentrionalia. 900 Balto-Finnic Proverb Types with

Russian, Baltic, German and Scandinavian Parallels. FFC 236. Helsinki.

Kõpp, Jaan 1902. Mõnda vanadest usukommetest Liivimaal Rootsi valitsuse ajal. Sirvilauad. Eesti rahva Tähtraamat 1903. aasta jaoks. Jurjev (Tartu), pp. 9-20.

Loorits, Oskar 1952. Grundzüge des estnischen Volksglaubens II. Lund

Loorits, Oskar 1941. Jurjev den v narodnoi traditsi ruskogo naselenia Estoni. Tartu.

Propp, V. 1963. Ruskye agrarnye prazdniki. Opyt istoriko-etnograficheskogo issledovania.

Leningrad.

Rantasalo, A. V. 1945. Der Weidegang im Volksaberglauben der Finnen I. FFC 134. Helsinki

Sakharov I. P. 1989. Skazania ruskogo naroda. Sobrannye I. P. Sakharovym. Moskva.

Skrodenis, S. 1968. Kalendorines apeigos, paprociai ir tautosaka. Dieveniskes. Vilnius, pp. 258-

266.

Shmits, Peeter 1940. Latvië̈u tautas ticejumi II. Riga.

Shapovalova T. T. 1974. Jegorjevski tsikl vesennikh kalendarnyh obryadov u slavyanskikh narodov i svjazannyi s nim folklor. Folklor $i$ etnografia. Obrjady i obrjadovyi folklor. Leningrad, pp. 125135.

Tampere, Herbert 1965. Kirde-Eesti rahvakalendri iseärasusi I. Slaavi-läänemeresoome suhete ajaloost. Tallinn, pp. 205-262.

Tolstaja S. 1984. Polesski narodnyi kalendar. Materialy k etnodialektnomu slovarju (A - G). Slavjanskoe i balkanskoe jasykoznanye. Jazyk v etnokulturnom aspekte. Moskva, pp. 178 - 200. Vilkuna, Kustaa 1982. Vuotuinen ajantieto. Vanhoista merkkipäivistä sekä kansanomaisesta talousja sääkalenterista enteineen. Helsinki. 